\title{
Rasgos de la apertura
} en Bataille y Didi-Huberman:

\section{una radicalización}

\section{de la imagen insumisa}

\section{The openness traits in Bataille and Didi-Huberman: radicalization of the insubordinate image}

Natalia Lorio*

Universidad Nacional de Córdoba, Argentina nalorio@unc.edu.ar 


\title{
Resumen
}

Proponemos sondear puntos fundamentales del pensamiento de Didi-Huberman sobre la imagen, a partir de la centralidad de conceptos, nociones y dispositivos metodológicos propiciados por Georges Bataille. Nos interesa, especialmente, mostrar que la antropología de las imágenes —en los trabajos más actuales derivada en una antropología política de las imágenes- de Didi-Huberman está atravesada por la apertura o el desgarramiento del saber, de la forma y la subjetividad que Bataille propone a lo largo de su obra. Así, la importancia metodológica, teórica y política de nociones críticas como no-saber, informe, heterogeneidad y soberanía serán piedra de toque para recorrer los hitos del antropomorfismo desgarrado batailleano y su impronta en la heurística didi-hubermaniana, subrayando la gravedad de la apertura y sus modalidades: como rasgadura epistémica de la historia del arte y el saber; como apuesta por la materialidad heterológica de las imágenes y como deslizamiento hacia el potencial sublevatorio de las imágenes.

Palabras Clave: imagen, no-saber, informe, Bataille, soberanía, sublevación, Didi-Huberman

\begin{abstract}
We propose some fundamental points of Georges Didi-Huberman's notion of the image, recognizing the centrality of a series of concepts and methodological devices promoted by Georges Bataille. We are especially interested in showing that the anthropology of images of Didi-Huberman -which in the most current works derives in one political anthropology of images-, is traversed by the opening of knowledge, opening of the form and subjectivity that Bataille proposes throughout his work. The methodological, theoretical, and political importance of critical notions such as Non-knowledge, formless, heterogeneity,
\end{abstract}


* Doctora en Filosofía por la Universidad Nacional de Córdoba, profesora y licenciada en Filosofía por la Universidad Nacional de Río Cuarto. Es docente de la Escuela de Filosofía, FFYH, UNC (cátedras Seminario metodológico e Introducción a la problemática filosófica). Forma parte de grupos de investigación y comunidades lectivas que propician cruces entre filosofía, psicoanálisis, política y arte. Publicó Georges Bataille. Una soberanía trágica (Adrogué: La cebra, 2019) y en coautoría con Verónica Meloni, Libro Párpado (Córdoba: Borde perdido, 2019). Sus textos han aparecido en diversas revistas nacionales e internacionales (El Banquete, Nombres, Pléyade, Areté, Representaciones, Avances, entre otras) y en libros colectivos. Actualmente dirige el proyecto de investigación Filosofía y psicoanálisis: Encuentros, influencias y discusiones (Ciffyh-FFYH-UNC) e integra el programa de investigación Actualidad de la crítica (SECYT-Universidad Nacional de Córdoba). 
sovereignty will be a guide to go through the Bataille's anthropomorphism and its imprint on the didi-huberman's heuristics, underlining the openness and its modalities: as an epistemic wounds in the history of art and knowledge, as a commitment to the heterological materiality of images and as a slide towards the potential of the uprising of images.

KEYwords: image, non-knowledge, formless, Bataille, sovereignty, uprising, Didi-Huberman

La revuelta a menudo tiene comienzos humildes, pero una vez iniciada ya no se detiene Georges Bataille, LA EXPERIENCIA INTERIOR

No es novedad decir que en el legado teórico de Georges Didi-Huberman podemos reconocer a Aby Warburg, Walter Benjamin, Carl Einstein y Georges Bataille. Un recorrido por su obra, por las insistencias y las diferentes estancias o focos de la misma, lleva a rastrear (casi cronológicamente) esas influencias $y$, si bien es posible constatar diferentes grados de cercanía o contundencia de cada lectura y pensamiento, es notable cómo la insistencia respecto a Bataille está atravesada por la figura de la apertura. Así, la apertura en tanto operación aparece en varios sentidos: en términos de una rasgadura epistémica — crítica del saber de la historia del arte y la historia de las imágenes—; en términos de una apertura de la imagen a la materialidad y la experiencia sensible promovida — alejada de lo ideal y la forma apolínea-; y en términos de una propuesta que se expone desde el antropomorfismo heterogéneo a pensar una experiencia interior radical de las imágenes - tensando hacia una política (de las imágenes) con lo cual abre la posibilidad de una sublevación-.

En atención a estos rasgos que aislamos para la reflexión sobre la operación de apertura, consideraremos los diferentes modos en que el pen- 
samiento de Bataille propicia, modula o acompaña los desarrollos teóricos de Didi-Huberman: a veces al ensanchar y profundizar la rotura de ciertas ideas e imágenes, otras mostrando los deslizamientos materiales que a partir de ciertas palabras y fulgurantes distinciones expanden la vía crítica de Didi-Huberman, o acaso al exhibir la metamorfosis de su propia obra y su decidida lectura de lo que subleva.

A sabiendas de la vastedad de la obra de Didi-Huberman, seleccionaremos algunas obras que nos permitan balizar mejor su perspectiva acerca de la historia del arte y su apuesta por una antropología de las imágenes, siempre siguiendo el rastro que lo contacta con Georges Bataille. ${ }^{1}$ En este marco, desarrollaremos la propuesta de un no-saber de las imágenes presente en las primeras obras de Didi-Huberman (como apuesta), la profundización de la antropología de las imágenes y de la imagen abierta, y el deslizamiento hacia una antropología política de las imágenes (en su producción más reciente).

En el primer apartado nos abocaremos a los retornos del no-saber batailleano para una puesta en crisis epistémica-metodológica de la historia del arte a la que apuesta Didi-Huberman en sus primeras obras - aunque claramente continúa, se acentúa e incluso posibilita las transgresiones disciplinares que se leen en sus estudios recientes-. En la segunda sección abordaremos la centralidad del materialismo bajo batailleano en la categoría de lo informe (desde Documents) y la condensación de la noción de imagen abierta de Didi-Huberman, en donde se muestran rasgos de la insubordinación material y heterogénea de la imagen. En la tercera parte presentaremos la profundización de la antropología política de las imágenes didi-hubermanianas, en donde es posible reconocer elementos de la operación batailleana en torno a la soberanía (mitologi-

Si bien en estos tramos de la obra didi-hubermaniana Bataille es convocado junto a muchos otros (puesto en tensión o en diálogo, entramado o plegado), aquí focalizaremos exclusivamente los alcances y retornos, puntos de contacto y contagio de Georges Bataille y Georges Didi-Huberman. 
zación y dramatización) y su apertura a una política de la insumisión en el planteamiento de una vida otra. Por último, finalizaremos con algunas consideraciones acerca de la trama compleja que aúna, en la experiencia radicalizada de las imágenes, no sólo una contorsión epistemológica, ni una crítica del sentido del arte, sino también una operación de apertura a registros y contagios de una memoria de la insumisión.

\section{Apertura al no-saber de las imágenes}

Es en Ante la imagen (1990) donde encontramos con contundencia el rasgo batailleano que tomará Georges Didi-Huberman para tensar su posición respecto a otros teóricos e historiadores del arte: ${ }^{2}$ nos referimos aquí al epígrafe que toma de La experiencia interior, el cual permite situar al historiador del arte abriendo su propio modo de hacer en la disciplina. Ese rasgo — veremos más adelante- está atravesado por cierta indisciplina, esa donde el saber no es la culminación; indisciplina que permite formular preguntas incómodas a la historia del arte y su saber pretencioso de decirlo todo, saberlo todo. Indisciplina que hace jugar un rol fuerte a lo pulsional.

En la apertura de Ante la imagen encontramos primero un fragmento de El concepto de Kuntswollen de E. Panofsky, donde se señala que la pretensión de la ciencia del arte está más allá de la comprensión meramente histórica del arte. A su vez, plantea las tensiones que atraviesan a esta ciencia: entre lo metodológico de la ciencia y su objeto (la obra de arte), por tanto, entre el elemento de normatividad propio de todo saber y de toda ciencia y la unicidad de la obra de arte; es decir, la unicidad de su

Georges Didi-Huberman, Ante la imagen. Pregunta formulada a los fines de una historia del arte (Murcia: Cendeac, 2010), 9. 
objeto, de cada uno de sus objetos. A este epígrafe, Georges Didi-Huberman opone otro fragmento que abre una llaga en la ciencia y en el saber:

\section{EL NO-SABER DESNUDA.}

Esta proposición es la cumbre, pero debe ser entendida así: desnuda, por lo tanto veo lo que el saber escondía hasta entonces, pero, si veo, sé. En efecto, sé, pero lo que supe también es desnudado por el no-saber. ${ }^{3}$

Al traer, al montar, al plegar ambos fragmentos, el gesto de Didi-Huberman parece afirmar un modo de hacer historia del arte, desde cierta (in) disciplina que supone el entramado de saber y no-saber. Dicho de otro modo, Bataille es traído aquí, casi arrastrado al inicio de esta obra, para reforzar el gesto propio de Didi-Huberman: pensar las paradojas del arte (de la historia del arte) y de las imágenes (de la historia de las imágenes), señalar su sentido disparado hacia otros tiempos, otros sujetos, otras experiencias.

Más aún, si consideramos que una teoría es una máquina óptica, este plegado hace ver que la inscripción del no-saber (su incrustación) en la historia del arte o el modo propuesto de estar ante la imagen didi-hubermaniana (de tomar posición) pueden extenderse a toda su obra. En la operación de "interrogar acerca del tono de certeza que reina tan a menudo en la bella disciplina de la historia del arte"4 encontramos ya la apertura en la cual no sólo se constata la fragilidad de la historia del arte y del saber ${ }^{5}$ sino que, además, se antepone la rajadura metodológica y teórica del no-saber.

Para dar cuenta de las implicancias de esta apertura, es preciso señalar que el no-saber batailleano tuvo diferentes nominaciones (heterología,

Georges Bataille, La experiencia interior. Suma ateológica I, de Silvio Mattoni, trad. (Buenos Aires: El cuenco de plata, 2016), 75.

Didi-Huberman, Ante la imagen, 12.

Recordemos también que, al apuntar esa fragilidad, se señala asimismo la modestia del historiador y su potencia en tanto fictor, aquel que modela, inventa con esa materia. 
ciencia de lo imposible), formulaciones (filosofía sagrada, antropología mitológica) y gestos (paródicos, dramáticos, cómicos), todos ellos indican un rasgo otro, inasimilable, irreductible. Así, el no-saber batailleano se opone a las satisfacciones del saber, estableciendo el deslizamiento del saber al no-saber. El no-saber contempla el fracaso de las operaciones del conocimiento, incluso el fracaso del lenguaje. Ese deslizamiento del saber al no-saber propuesto por Bataille (y contagiado a Didi-Huberman) implica una crítica al saber y a la ciencia (al proyecto, el mundo del trabajo y la servidumbre) en donde la experiencia del tiempo queda atrapada en la postergación y en la duración.

En La experiencia interior ${ }^{6}$ Bataille refiere que el saber, dado en el tiempo y en el discurso, implica la satisfacción tras la operación completa que supone el esfuerzo humano, su servidumbre (por eso asegura que "el saber trabaja"). ${ }^{7}$ Frente a esto, el no-saber se inscribe en la experiencia interior o la operación soberana hacia la aniquilación del pensamiento en tanto servidumbre. El fracaso del saber señala el deslizamiento hacia el no-saber. En esta parte de la Suma ateológica, Bataille realiza una crítica al saber hegeliano, a su circularidad y su acabamiento, para luego considerar su corrimiento: el no-saber, mediante la dislocación de la noción de experiencia, estará abierto a la desgarradura, a la herida, a lo inacabado, lo desconocido, y al instante.

En estos dos fragmentos de la Cuarta parte de La experiencia interior citados a continuación se reconoce mejor la provocación batailleana y lo que supone el movimiento del saber al no-saber. En el apartado "III. Hegel" afirma:

Conocer quiere decir: remitir a lo conocido, entender que una cosa desconocida es la misma que otra conocida. Lo que supone o bien un suelo firme 
donde todo se apoya (Descartes), o la circularidad del saber (Hegel) [...] La cadena sin fin de las cosas conocidas no es para el conocimiento más que el acabamiento de sí mismo. La satisfacción se refiere al hecho de que un proyecto de saber, que existía, ha llegado a sus fines, está cumplido, que ya no queda nada por descubrir (nada importante al menos). ${ }^{8}$

A pocas páginas, en el apartado "IV. El éxtasis" sostiene:

El no-saber comunica el éxtasis — pero solamente si la posibilidad (el movimiento) de éxtasis ya pertenecía, en alguna medida, a aquel que se despoja del saber [...] El movimiento anterior al éxtasis del no-saber es el éxtasis ante un objeto (ya sea que se trate del punto puro, como requiere la renuncia a las creencias dogmáticas, o cualquier imagen perturbadora). ${ }^{9}$

Este deslizamiento al no-saber carga las tintas sobre la experiencia y cuenta con diversas aristas: salir del discurso de la razón, del saber como proyecto; revela la importancia de la comunicación (en la cual el sujeto está abierto); supone borrar al sujeto, cuyo punto extremo no es alcanzado hasta ser comunicado (ya no hay objeto ni sujeto, sino la brecha distendida entre ambos); el no-saber no sólo comunica el éxtasis, sino que se opone al saber y a la satisfacción de éste.

Según Bataille lo propio del saber es ordenar, definir y trazar — a cierta distancia- los límites de lo cognoscible, mientras que el no-saber interrumpe esa distancia instaurada, corta la subordinación del objeto (o de las imágenes) al sujeto en la experiencia, la convierte en una desnudez que rehúye de aquello que puede ser dicho fácilmente. En el no-saber, la experiencia es protagonista: "La experiencia es la puesta en cuestión (a prueba), en la fiebre y la angustia, de lo que un hombre sabe por el he-

Bataille, La experiencia, 138.

Bataille, La experiencia, 154. 
cho de ser"; ${ }^{10}$ si bien hay allí algún tipo de aprehensión, también ésta no permite un enunciado descriptivo sin más, o una representación como las construidas desde el saber. Se trata, por el contrario, de una aprehensión que en todo caso escapa al entendimiento. Lo que Bataille considera experiencia interior es aquella que exige la desnudez; mas si el trabajo del discurso es cubrir la desnudez de la experiencia, decir desnudez $-\mathrm{O}$ comunicación o éxtasis - es tensar el acceso a algo que no es un saber.

Este movimiento del saber a la desgarradura del no-saber, retomado por Didi-Huberman, nos permite establecer una suerte de paralelismo y señalar los diversos marcos del no-saber en cada perspectiva teórica, en cada campo de batalla disciplinar: la postulación del no-saber en Bataille se opone a Hegel, o mejor, transgrede el sistema del saber hegeliano. ${ }^{11} \mathrm{El}$ gesto de Didi-Huberman se amplifica con el psicoanálisis (y el nombre de Freud se pone en tensión con Kant y con el postkantismo), para habilitar una historia del arte y una teoría de las imágenes desde un entramado donde el sujeto y el arte son pensados como desgarros, lo que permite "reabrir también de forma decisiva la cuestión del saber". ${ }^{12}$

Ya en Ante la imagen, obra temprana de Didi-Huberman, reabrir el saber supone una suerte de economía en torno a las imágenes, inclinada más hacia la pérdida que hacia la ganancia (otra impronta batailleana). ${ }^{13}$

10 Bataille, La experiencia, 25.

11 Sasso afirma la existencia de un sistema del no-saber en Bataille, como transgresión al sistema del saber hegeliano. De allí señala la subordinación del saber como trabajo en Hegel y el despliegue establecido por Bataille al hacer coincidir su nuevo discurso con la impotencia del discurso. Sin embargo, Sasso complejiza la afirmación de un sistema del no-saber al señalar que éste debe ser pensado a partir de su inacabamiento, en una ontología del juego. "Sistema inacabado del no-saber" que ya desde su denominación excede todo posible ajuste al sistema. Robert Sasso, Georges Bataille: Le système du non-savoir. Une ontologie du jeu (París: Éditions de Minuit, 1978), 77 y ss.

12 Didi-Huberman, Ante la imagen, 17. La cursiva es nuestra.

13 Recordemos la importancia del gasto y la propuesta de una economía general en la obra batailleana, que sitúa al arte y sus manifestaciones dentro de una economía de la energía, del exceso y la comunicación, especialmente en La noción de gasto, La parte Maldita y Lo que entiendo por soberanía. Georges Bataille, Euvres complètes vols. VII, VIII (París: Gallimard, 1970-1988). 
En este terreno, la apuesta de Didi-Huberman es dialectizar saber y no-saber, aquello que se sabe de la imagen con lo que deslumbra en las imágenes y, desde la senda del paradigma crítico del psicoanálisis, pensar la repetición, el apres coup, la deformación en la imagen.

Por lo pronto, subrayemos que Didi-Huberman retoma la experiencia interior batailleana como una heurística: "el no-saber acomodado en el saber o el desgarro incluido en la trama", ${ }^{14}$ en la historia del arte, en las imágenes y en lo producido por su contacto. Incluso, con el psicoanálisis (¿también como no-saber o más bien como gayo saber?), esta heurística atravesada por el no-saber propone un modo de acceso a esta experiencia con las imágenes que, lejos de estar fijada por lo que el saber ya sabe, se deja afectar por el valor de aura de las imágenes (dicho con Benjamin) o se deja fascinar (con Bataille) por su valor heterogéneo o sagrado. Este gayo saber:

Se funda sobre la hipótesis general de que las imágenes no deben su eficacia a la única transmisión de saberes — visibles, legibles o invisibles—, sino que, al contrario, su eficacia actúa constantemente en el lazo, incluso en el embrollo de saberes transmitidos y dislocados, de no-saberes producidos y transformados. Exige, por lo tanto, una mirada que no sólo se acercaría para discernir y reconocer, para nombrar a toda costa lo que comprende — pero que, en primer lugar, se alejaría un poco y se abstendría de clarificarlo todo enseguida - . [... En esta alternativa estaría entonces la etapa dialéctica — probablemente impensable para un positivismo- que consiste en no apoderarse de la imagen y en dejar, más bien, que ella se apodere de uno: luego, en dejarse desposeer de su saber sobre ella. El riesgo es importante, claro está. Es el riesgo más bello de la ficción. ${ }^{15}$

14 Didi-Huberman, Ante la imagen, 18.

15 Didi-Huberman, Ante la imagen, 27. 
En esta fenomenología de la mirada reconocemos subterráneamente a Bataille y de manera explícita al psicoanálisis —en tanto crítica, no como clínica—, ${ }^{16}$ para imaginar con el saber histórico las obras y el arte como "hacer pasar en sus obras la cadena del saber, pero también romperla hasta deshilacharla del todo, para desplazar los recorridos y hacerlos significar en otra parte, de otra manera". ${ }^{17}$

Bajo la matriz abierta del no-saber, en esta trama del saber que incluye al no-saber, que se rompe y perturba, vale insistir sobre el rol de la imagen en ese movimiento - tan presente en Bataille en el marco de lo que llamó una operación soberana; asumida y potenciada en la propuesta teórica didi-hubermaniana. En Lo que vemos, lo que nos mira (1992) se intensifica el rasgo de la apertura a la imagen (a una forma, a un volumen) por la mirada: es por la vía del psicoanálisis freudiano que la dialéctica de lo visual — que estalla la oposición entre lo visible/invisible — y la imagen dialéctica benjaminiana —oposición entre antaño/ahora, juego/ crítica - son presentadas desde la matriz pulsional donde la imagen es "portadora de una latencia y una energética". ${ }^{18}$ Benjamin, Leiris, Einstein, Warburg y Bataille son retomados en esta obra y atravesados por el psicoanálisis, en una escansión pulsátil de lo que se abre y se cierra, en el movimiento de diástole y sístole del pliegue de las imágenes. Desde allí Didi-Huberman indica los vestigios de un gayo saber de las imágenes, acaso como una promesa para sí mismo, para su trabajo teórico:

16 Fue Charcot quien llevó a cabo una clínica de imágenes. Los saberes clínicos de la hagiografía de las histéricas de Salpêtrière (que él mismo definió como museo patológico vivo) construyen saber, inventan un saber sobre la histeria y las fotografías se convirtieron en un ojo clínico absoluto, un espacio más del saber. Didi-Huberman señala la coherencia epistemológica y práctica que Charcot subraya en esa fábrica de imágenes: coherencia que anuda su proyecto científico, terapéutico y pedagógico. Georges Didi-Huberman, La invención de la histeria. Charcot y la iconografía fotográfica de Salpêtrière, Tania Arias y Rafael Jackson, trad. (Madrid: Editorial Cátedra, 2015), 23-91.

17 Didi-Huberman, Ante la imagen, 27.

18 Georges Didi-Huberman, Lo que vemos, lo que nos mira, Horacio Pons, trad. (Buenos Aires: Manantial, 2010), 61 . 
Consideremos para terminar el destino textual de la imagen dialéctica en algo que, al leer a Benjamin [pero también a sus contemporáneos Bataille, Leiris o Carl Einstein], me gustaría llamar gayo saber, cuando construye su propia novedad configuracional en una práctica — por definición abierta e inquieta por sus fundamentos mismos - en el que escribir se abre un paso para superar la clausura del ver y la del creer. $^{19}$

Ese gayo saber, jovial y crítico de las imágenes y de la historia del arte, no sólo señala la promesa teórica de Georges Didi-Huberman, ${ }^{20}$ sino que permite captar su inscripción en un legado, en la constelación de miradas y la estela de escrituras un tanto díscolas respecto al saber. Dicho saber puede dejarse atravesar por su momento de pérdida, por la experiencia de la ambigüedad y la ambivalencia, por la desemejanza. Esa práctica — transgresora de estilos - asume que la distancia es siempre doble, que el aura es la aparición de la distancia en una rítmica, donde el juego y la infancia se tensan con el vértigo del lenguaje. ${ }^{21}$ Esa práctica del saber destellante y pulsátil, que puede tomar a su cargo las imágenes y su supervivencia, su latencia y anacronismo, es a la vez un paradigma

19 Didi-Huberman, Lo que vemos, 121.

20 En el desarrollo de la propuesta didi-hubermaniana se hace patente la reformulación del tiempo histórico inherente a un pensamiento sobre la imagen: la articulación de tiempo e imagen, de la mano de Walter Benjamin y Aby Warburg, seńala hacia la emergencia del tiempo anacrónico y la sobredeterminación de las imágenes. El modo en que esta heurística puede reconocer la plasticidad y la heterogeneidad de tiempos que operan en cada imagen es piedra de toque para pensar el pasado e interrogarlo, allí donde asoman discontinuidades, tiempos incumplidos, montajes. Acerca de esta perspectiva para pensar la estética y las letras, ver el texto de Ana Neuburger, "El presente y sus restos. Arte, literatura e imagen en la estética contemporánea”, La Palabra 37 (abril-junio de 2020), 41-56. https://doi.org/ 10.19053/01218530.n37.2020.8950.

Sobre las derivas para pensar historia, estética y memoria, ver el libro de Luis García, La comunidad en montaje. Imaginación política y postdictadura (Buenos Aires: Prometeo, 2018).

${ }_{21}$ Ver Michel Leiris, "La regla del juego", en Philippe Ollé-Laprune, Para leer a Michel Leiris, Glenn Gallardo, Flora Botton Burlá, Jorge Ferreiro, Mónica Mansour y Virginia Jaua, trads. (Ciudad de México: Fondo de Cultura Económica, 2010).

108 / Revista de Filosofía · año 53 · núm. 151 · julio-diciembre 2021 
crítico desde donde interrogar el sentido de los conflictos y las luchas en la historia del arte. ${ }^{22}$

Por último, este saber que incluye su propio desgarro, lejos de la inefabilidad, toma la escritura para producir la apertura de las imágenes. Si Benjamin le había dictado al oído a Didi-Huberman que "la lengua es el lugar en donde es posible encontrar", ${ }^{23}$ Bataille ${ }^{24}$ (junto a Einstein y Leiris en la década de 1930) le muestra los choques estrepitosos de esos encuentros en una práctica escritural anti-académica e informe que hizo posible Documents.

\section{Apertura a lo informe}

Como es sabido, La ressemblance informe ou le Gai Savoir visuel selon Georges Bataille (1995) está íntegramente abocado al estudio en profundidad de Bataille. En esta obra Georges Didi-Huberman acomete la tarea de pensar los modos en que Bataille tomó la imagen, o mejor, se dejó tomar por las imágenes, y presenta ese tipo de saber crítico y jovial que denomina gayo saber. Las apuestas metodológicas señaladas, previas a La ressemblance informe, toman cuerpo en este texto dedicado a pensar en profundidad y extensión la obra de Bataille en cuanto a la semejanza informe. Aquí, la dialéctica de las imágenes es pensada en términos de

22 Didi-Huberman, Lo que vemos, 152. La centralidad de Carl Einstein y su apuesta en Documents será retomada en numerosas obras de Didi-Huberman, principalmente en Ante el tiempo. Historia del arte y anacronismo de las imágenes, Antonio Oviedo, trad. (Buenos Aires: Adriana Hidalgo, 2011).

23 Didi-Huberman, Lo que vemos, 121.

24 Didi-Huberman rescata el modo en que Foucault sitúa a Bataille como un antecesor —y su arqueología en constelación con la heterología batailleana-, lo considera escritor y no filósofo, no tanto para "debilitar la crucial contribución del marginal Bataille a la aventura del pensamiento", sino para remarcar "lo profundo de una escritura de la vida y no de un conjunto de ideas organizadas en sistema [...] lo que supone una cierta vida artista, para utilizar el vocabulario foucaultiano del seminario de 1984". Ver Georges Didi-Huberman, "El arte de la vida otra, o cómo no ser gobernado" en CHUY Revista de estudios literarios latinoamericanos 5 (diciembre de 2018), 9. 
lo sintomático, siguiendo la huella del psicoanálisis presente en trabajos anteriores, en los cuales es posible captar el deslizamiento respecto al saber. Didi-Huberman posiciona su propia lectura en la estela batailleana: una inscripción que bien puede pensarse como la puesta en acto de una heterología a partir de las imágenes.

En La ressemblance informe Didi-Huberman despliega exhaustiva y ampliamente la búsqueda de estas pistas en la obra de Bataille, en donde se hace presente la imagen abierta, tanto en sentido estético como en aquello que entendemos como ontológico. Aquí es clave indicar que, según Bataille, el arte aparece como el vector, el vehículo, la instancia y el espacio de una experiencia de comunicación, de éxtasis, de desgarramiento; en este sentido, la experiencia no es meramente una estética, o lo es, pero en un sentido radicalísimo que transgrede lo bello, que apuesta por el horror y por la impresión y la puesta en contacto. De allí que insistamos en lo que captamos como un rasgo ontológico: la puesta en juego de la comunicación, mediante el arte (como efusión soberana), precipita toda una perspectiva ontológica relacional de conmoción y movilidad dentro-fuera, sin dejar de asumir esa distancia, sin la cual no sería posible ese movimiento.

De este modo, aparece como una categoría central la abertura — ranura, orificio, pero sobre todo resquebrajadura - en términos ontológicos, que a nuestros ojos aparece como soporte de la noción de imagen abierta didi-hubermaniana. Didi-Huberman rastrea los modos en que esa imagen abierta está en Bataille atravesada por lo informe, por la desclausura de la forma (cerrada, ideal), ahora desollada, abierta a una interioridad, desnuda. Esta matriz — atravesada por la fascinación de una imagen que se abre de la forma sintesis a la forma sintoma - toma como clave de lectura lo sintomático: la imagen conjuga un materialismo bajo con una interpretación de la tensión, de la intensidad y la energética pulsional. En esta clave, la imagen está atravesada por una operación sobre la forma que no busca tanto la claridad y la distinción, como dar cabida al inconsciente y lo maldito, lo sagrado y lo heterogéneo: 
Hay entonces dos modelos de la dialéctica de las formas. Está la dialéctica del buen estudiante o del policía, bien pensante, trivial porque aplica, todo a su deseo de control, que se enuncia como se debe: tesis-antitesis-sintesis. Y está también la dialéctica del bribón, del sinvergüenza que juega a romper, de los Pied Nickelé, ${ }^{25}$ de la pintura cubista, de lo herético o del cineasta moderno. Esta dialéctica, a la vez inquieta y juguetona, atravesada tanto por el gayo saber como por una conciencia desgarrada —en resumen, por un cierto sentido de la crueldad de las cosas - esta dialéctica se enuncia ahora como: tesis-antitesis-sintoma. ${ }^{26}$

Desde aquí, el texto de Didi-Huberman sobre Bataille y su operación sobre las imágenes se presentan a partir de una tesis, una antítesis y no una síntesis conclusiva del saber, sino de una dialéctica sintomal, la cual desestabiliza el campo de la estética y la filosofía. Es necesario señalar que, si bien en La ressemblace informe es central, el tratamiento sobre la aventura estética que significó Documents, ${ }^{27}$ toda la obra de Bataille se

25 En alusión a los cómics con dicho nombre (acerca de las aventuras de esos jóvenes anarquistas), que remiten a esos "pies niquelados", el apodo a la vagancia.

26 Georges Didi-Huberman, La ressemblance informe ou Le gai savoir visuel selon Georges Bataille (París: Macula, 1995), 296. La traducción es nuestra.

27 La tentativa de esta publicación heterodoxa (que reunía textos e imágenes de las llamadas Beaux arts, las sciences humaines, literatura, etnografía de forma no habitual por aquellos ańos) fue la de hacer frente a la limitación de lo sensible, explotar sus sentidos, excavar en lo bajo y exponerlo. Dicha tentativa no sólo se hace patente en el "montaje" de una serie de discursos e imágenes que mostraban la tensión en torno a la cultura, también en la construcción de un "Diccionario crítico" que diera otro valor a las palabras: una serie de artículos y entradas del diccionario crítico aparecidos en la revista Documents van en este sentido (de Bataille: "El bajo materialismo y la gnosis", "El lenguaje de las flores", "Figura humana", "Materialismo", "Informe"). Para un estudio en profundidad de Documents remitimos a Colectiva materia (coord.), Indisciplina. estética, politica y ontología en la revista Documents (Buenos Aires: Ragif ediciones, 2018); Marisa García Vergara, Georges Bataille y la parte del arte. De Documents a Acéphale (Barcelona: Universitat Autònoma de Barcelona, Universitat de Barcelona, Universitat de Girona, Universidad de Lleida, Universitat Politècnica de Catalunya, Universitat Rovira i Virgili, Museu Nacional d'Art de Catalunya, 2013). 
aborda en pos de reconocer los siguientes movimientos: la semejanza y la conformidad desgarradas a partir de una crítica a la iconografía y la asunción del contacto de las imágenes en un materialismo insumiso (tesis); la desproporción y lo informe, la descomposición del antropomorfismo batailleano en una violenta desmentida de la figura humana (antítesis); y la metamorfosis de las formas en la dialéctica negativa que abre la filosofía, encarnada en una dialéctica sintomal que puede tocar lo bajo y exponerse a lo informe (síntoma).

El rasgo sintomal que deshilacha la trama del saber y abre la imagen a lo informe, según esta lectura, está presente tanto en la operación concreta de montaje en Documents, ${ }^{28}$ como en la invención o el entramado de una ciencia imposible o heterología, en las tensiones y los movimientos que Bataille configura en los cuadros heterológicos; ${ }^{29}$ pero también en la perturbación de la filosofía en su Suma ateológica, en donde el éxtasis visual conmociona y perturba la noción de espectáculo y las certezas estéticas. La perturbación del régimen del sentido está propiciada por lo irre-

La revista Documents (publicación aparecida entre 1929 y 1930) reunió a Georges Bataille, Michel Leiris, Carl Einstein, Georges Henri Riviere, Marcel Griaule, Marcel Mauss, Jacques Prevèrt, entre otros hombres de las artes, las ciencias humanas y las letras. Desde sus inicios marcó un nuevo modo de pensar la materialidad de la cultura y las imágenes (de ahí "documentos" como constancia en la historia del pensamiento que se hace escritura, de la imaginación que se hace imagen, de la visión que se hace fotografía, de la comunicación que produce arte... se hacen presentes la experimentación de las vanguardias artísticas, la adscripción a la política revolucionaria y la contundencia del malestar de la cultura). Ver la edición presentada por Denis Hollier, Documents (París: Jean Michel Place, 1991). Para acceder a la revista Documents digitalizada redirigimos a https://gallica.bnf.fr/ ark:/12148/bpt6k32952s.

29 Los cuadros heterológicos ponen en movimiento polarizaciones de lo más variadas entre lo alto y lo bajo, entre las formas ideales y lo informe o monstruoso, remitiendo a hitos temáticos como: guerra, arte, asesinato, mujer, sexualidad, dios, mundo metafísico, héroe, gasto, sagrado, muerte, diferenciación social, entre otros. Para profundizar en los caracteres de la heterología y las cuestiones de método derivadas, remitimos a: Natalia Lorio, "Heterología. Cuestiones de método y otras consideraciones", en Métodos. Aproximaciones a un campo problemático (Buenos Aires: Prometeo, 2018), 177-193.

112 / Revista de Filosofía · año 53 · núm. 151 · julio-diciembre 2021 
ductible de la investidura libidinal, que Bataille inscribió en unas sciences humaines un tanto inquietas e inquietantes. Como advierte Didi-Huberman, la perturbación del sentido en esas épocas de impugnación revolucionaria y tensión vanguardista no se da tanto por la disolución de las formas, sino por su metamorfosis, posibilitando: "una infernal dialéctica de las formas [...], una inextricable contradicción [...] vinculada a la propia estructura psíquica del deseo de ver". ${ }^{30}$

La fascinación por lo inaceptable, modulada de diversas formas por Bataille, encuentra en Documents el modo de plantear un materialismo que pone en jaque no sólo a la ontoteología, sino también al dispositivo humanista inscrito en el mismo. Bataille opondrá al idealismo (o a los idealismos hegeliano, surrealista, moralista, estético) lo inaceptable que lo ruin, lo pútrido y lo bajo encarnan. Convoca así a Sade, Freud, Nietzsche, Picasso, entre otros, en una investigación material de la cultura en pos de abolir una imagen aceptable, acordada, higiénica de la misma.

En una suerte de trazado de transgresiones y tensiones disciplinares, los textos batailleanos en la revista dejan al descubierto la potencia de la insumisión de la materia: al lenguaje, a las formas restringidas y las valoraciones, al sentido. La pretensión de Documents (impulsada por Bataille) de enfatizar la perversión de las formas en las representaciones artísticas y recalcar lo inadmisible e inhumano en lo humano y más allá encuentra su modulación en el transvasamiento de lo sensible y lo disciplinar por la escritura y la imagen. Insistir sobre lo informe supone también insistir sobre los modos de dar cuenta de esa informidad. En la entrada "informe” del Diccionario crítico (sección de Documents) se lee lo siguiente:

30 Georges Didi-Huberman, La dama duende, Lucía Montes Sánchez, trad. (Madrid: Avarigani Editores, 2019), 27. En este texto, Didi-Huberman da cuenta, a partir de la figura del duende (demonio, figura infantil, criatura de deseo, espíritu bajo y maligno del arte), de la contradicción batailleana respecto al arte: que puede ser índice de celebración dionisiaca, ligada a la descomposición de la risa y la fiesta, y también herida, mancilla, muerte, exceso. Didi-Huberman, La dama, 57-60. 
En efecto, para que los académicos estén contentos sería necesario que el universo tomara forma. La filosofía entera no tiene otro fin: se trata de otorgar una levita a lo que es, una levita matemática. En cambio, afirmar que el universo no se parece a nada y sólo es informe es lo mismo que decir que el universo es algo parecido a una arańa o un escupitajo. ${ }^{31}$

Esa desestabilización de las formas, heridas de muerte por lo informe como matriz estructural, supone el movimiento que implica la ontología batailleana, aquella que más tarde abordará en la Suma ateológica como un "principio de insuficiencia" expuesto al contacto, o la apertura que permite la comunicación. Lo informe es índice y factor del paso de lo semejante a lo desemejante, así "lo informe no califica en absoluto a los términos - las 'cosas informes' en tanto que tales—, sino a las relaciones: lo informe no es ni una pura y simple negación de la forma, ni una pura y simple ausencia de forma". ${ }^{2}$

No obstante, consideramos que no es posible comprender la heurística batailleana de lo informe si no en relación al materialismo insumiso que la permea. La materia es insumisa, está expuesta al movimiento, a la adherencia, a la desproporción. Dicho de otro modo, es la materia la que se insubordina a quedar presa en la cárcel burocrática de la separación y jerarquización de saberes y ciencias, incluso de una sensibilidad ajustada a una aséptica de la percepción. Lejos de eso, Bataille inocula el mal en la percepción y allí la materia aparece como un principio activo, autónomo, ligado al mal (en tanto el mal es irreductible al principio moral).

En Documents Bataille traza un materialismo recalcitrante a la ontología que haría de la materia la cosa en sí. La materia aparece en su descomposición, en su monstruosidad, en su potencia y en su rebelión. Si bien en toda la revista la materia se muestra como un principio no

31 Georges Bataille, Documentos, Inés Cano, trad. (Caracas: Monte Ávila editores, 1968), 145.
32 Didi-Huberman, La ressemblance, 134. 
subordinado, los abordajes de Bataille y Leiris son los más contundentes y extremos: se trata de documentar la heterogeneidad haciendo regir una heurística relacional que articula metamorfosis sobre metáfora en una transfiguración, transformación y traslado de sentidos, de saberes, de experiencias. En ese movimiento, al salir fuera de sí, materia y lenguaje aparecen inquietos, impuros, en formas desconocidas, alterando también el antropomorfismo.

La serie de textos de Georges Bataille aparecida en Documents y el tipo de operación material de registro de las imágenes pretendían poner en contacto la cultura con la materia baja, a sabiendas de que ésta no se condice con ninguna idea, con ninguna forma ideal. Los textos batailleanos que consideramos aquí permiten reconocer lo que nos interesa denominar un materialismo insumiso: arremete tanto contra el idealismo hegeliano como contra el materialismo mecanicista; en donde el rol de las imágenes es clave en el señalamiento de lo sensible y la exploración de sus sentidos. Las cualidades propias de este materialismo (al que no le son desconocidos los elementos heterogéneos del inconsciente ni de lo sagrado ni de las artes) tejen una tradición, otra de las sciences humaines en la que están reunidos tanto Freud, Hubert y Mauss como Picasso. En este materialismo insumiso no sólo es reconocible el pliegue entre materia, imagen y lenguaje reconocido por Didi-Huberman, ${ }^{33}$ sino también una marca interesante de insumisión que Didi-Huberman hace suya, recupera y despliega en su obra ${ }^{34}$ y sus intervenciones ${ }^{35}$ más recientes.

33 Didi-Huberman, La ressemblance, 280-345.

34 Didi-Huberman, "El arte de la vida otra”, 16-17. También Georges Didi-Huberman, "Por los deseos (fragmentos sobre lo que nos subleva)", en Sublevaciones, Susanna Méndez, Xavier Rodrigo y Mercè Ubach, trads. (Saenz Peña: Jeu de Paume-Eduntref, 2017) y Georges Didi-Huberman, Desear desobedecer. Lo que nos levanta, 1, Juan Calatrava y Alessandra Vignotto, trads. (Madrid: Abada Editores, 2020).

35 Ver la muestra itinerante Sublevaciones organizada por el Jeu de Paume (entre 2017 y 2018), cuya curaduría estuvo a cargo de Didi-Huberman. De París a Barcelona, Buenos Aires y México el trabajo curatorial (contundente atlas itinerante de la sublevación) opera concretamente con la semejanza, 
$\mathrm{Al}$ documentar este materialismo bajo, Bataille se instala en franca oposición a cierto idealismo de lo onírico — encarnado en la revuelta surrealista liderada por Breton-, iniciando un dispositivo donde se expone el exceso (de la desemejanza) de las formas, se descompone la idealidad de lo humano, se tuerce lo ideal hacia lo informe en un ejercicio de crueldad jocosa, como dirá Didi-Huberman. ${ }^{36}$ La fascinación por lo informe o por el aplastamiento de la semejanza perturba no sólo al régimen del saber de las imágenes, sino también al modo de "saber verlas", incluso de "vérselas con las imágenes". Con esto señalamos que la desjerarquización arremete contra el uso de las imágenes, ya que, por un lado, las imágenes no ilustran los textos, se incrustan en ellos, se pliegan e inventan otro régimen de lo textual; por otro lado, el uso de las imágenes está atravesado por su heterogeneidad material (su valor de uso es heterogéneo, ${ }^{37}$ o sea, carga con una fuerza o energía sagrada, es decir, marca la distancia y a la vez pone en contacto). Es en este marco materialista y heterológico "que esta experiencia cobra su valor y su autoridad: no es una sustancia lo que allí está puesto en juego, sino sus desgarramientos, no la contemplación de una plenitud, sino los movimientos de contagio y comunicación que dan cuenta de la insuficiencia de los seres, su pasaje al límite". ${ }^{38}$

los rasgos y motivos de insumisión y no-servidumbre y apela a una materialidad móvil y cambiante de las imágenes en el contagio de una memoria y una potencia contra lo que nos aplasta. https:// untref.edu.ar/muntref/sublevaciones/

36 Didi-Huberman, La ressemblance, 233-240.

37 Sobre la cuestión de lo heterogéneo y sus rasgos en la escritura de Georges Bataille consideramos central no sólo el humus de la filosofía fragmentaria de Nietzsche, sino también su conjunción con los procesos de condensación y desplazamiento del inconsciente en Freud y la caracterización de lo sagrado en Durkheim, en tanto separado y heterogéneo a lo profano y al contacto habitual. Sobre algunos rasgos de la escritura batailleana en estos términos remitimos a Natalia Lorio "Una escritura a la caza de lo real. Lo heterogéneo, lo sagrado y la soberanía en Georges Bataille", El laberinto de arena, núm. 2 vol. 1 (invierno/primavera de 2013) http://www.hum.unrc.edu.ar/ojs/index.php/ Filosofia/index.

38 Natalia Lorio, Georges Bataille. Una soberanía trágica (Adrogué: La cebra, 2019), 228. 
En Bataille el valor de uso heterogéneo de las imágenes está regido por la tentativa de tocar lo imposible: tocar materialmente lo imposible, un tocar materialmente imposible. Aquí es central la caracterización del materialismo y de la materia en tanto condensación de lo imposible. En la entrada "Materialismo" (Documents núm. 3, junio de 1929) Bataille denuncia la persistencia, en la mayor parte de los materialistas, de la voluntad de "describir un orden de cosas caracterizado por relaciones jerárquicas", desde una matriz idealista, situando "a la materia muerta en la cima de una jerarquía convencional de hechos de diverso orden, sin percibir que de esa manera cedían a la obsesión por la forma ideal de la materia, de una forma que se acercaría más que ninguna otra a lo que la materia debiera ser". ${ }^{39}$ Pero, ¿`cómo es posible que la materia muerta sea puesta aquí en relación con "la idea y Dios"? El sentido que tiene "materia muerta" en este diccionario (no del sentido, sino de las necesidades) es el de señalar y denunciar este modo estático y dócil con el cual se pretende "vestir" a la materia, buscando que responda a una misma forma, a la pregunta por la esencia de las cosas (es decir, que responda "tan llanamente como un alumno dócil en clase, a una pregunta que sólo puede ser formulada por filósofos idealistas, a la pregunta de la esencia de las cosas, exactamente de la idea por la cual las cosas se tornan inteligibles"). ${ }^{40}$

Frente al "deber ser de toda apariencia" o la "conformidad de la materia muerta a la idea" ${ }^{41}$ donde el "elemento estable" permite a las ciencias lograr la inteligibilidad de las cosas, Bataille marca su viraje hacia un materialismo de lo informe e inestable, no emparentado con ningún “idealismo decadente”. Este materialismo se basará no en los fenómenos físicos, sino en hechos psicológicos o sociales:

$\begin{array}{ll}39 & \text { Bataille, Documentos, } 148 . \\ 40 & \text { Bataille, Documentos, } 147 . \\ 41 & \text { Bataille, Documentos, } 148 .\end{array}$ 
Por lo tanto es a Freud, entre otros — más que a médicos muertos hace tiempo y cuyas concepciones están hoy fuera de toda consideración- a quien debemos solicitar una concepción de la materia [...] Al emplear la palabra materialismo ya es hora de designar la interpretación directa, carente de todo idealismo, de los fenómenos brutos y no un sistema fundado sobre los elementos fragmentados de un análisis ideológico elaborado bajo el signo de las relaciones religiosas. ${ }^{42}$

En "El bajo materialismo y la gnosis" (1930) encontramos también ese combate contra la arbitrariedad que sostiene el andamiaje de la metafísica. Si la idea o el Dios abstracto constituyen el estigma metafísico que lleva a una abstracción sistemática, en donde la materia aparece relegada o cubierta por el manto de lo abstracto, el materialismo insumiso propuesto por Bataille tiende a desencadenar la materia. Así, liberarla de su yugo (hegeliano o religioso) y proponer un materialismo de lo bajo es, en definitiva, hacer lugar a lo que hay de monstruoso y obsceno en la materia, hacer lugar a lo imposible de la materia. Recuperar a los gnósticos y ese carácter maldito constitutivo de la materia es el modo de afirmar las fuerzas y agitaciones que obran en la misma. La materia aparece como un principio activo, autónomo, ${ }^{43}$ ligado al mal y este último es irreductible al principio moral, es más bien contacto y apertura.

Las imágenes gnósticas de arcontes con cabeza de pato, de un dios con efigie de asno solar señalan una figuración del mundo en la cual la materia misma se muestra en su contradicción, en ella aparecen otros caracteres de este materialismo: el leit motiv del gnosticismo que concibe la materia como un principio activo eterno y autónomo del mal, ligado a sus propias obsesiones sobre lo inadmisible, el mal irreductible al principio moral y en tanto motor de la creación. Las figuras de los arcontes

\footnotetext{
42 Bataille, Documentos, 148.
}

43 Bataille, Documentos, 84 . 
con cabezas animales, representación de la autoridad bajo cuyo dominio está el mundo, conllevan a concebir una "rebelión desvergonzada contra el idealismo del poder" y contra Dios: "Por haber recurrido a los arcontes, no pareciera que hayamos deseado profundamente la sumisión de las cosas que pertenecen a una autoridad superior, a una autoridad que los arcontes confunden con una bestialidad eterna" ${ }^{44}$

Aquello reconocido en la gnosis como inversión del idealismo, conduce a Bataille a posicionarse en una suerte de materialismo recalcitrante a la ontología, que hará de la materia la cosa en sí. La materia no es ella misma una autoridad, pues, en ese caso, tomaría el valor superior que se quiere evitar y sustituiría una servidumbre por otra. "La materia baja es exterior y extraña a las aspiraciones humanas ideales y rechaza dejarse reducir a las grandes máquinas ontológicas derivadas de esas aspiraciones" ${ }^{45}$

Vale aclarar que "las máquinas ontológicas" del idealismo tienen sus propias figuraciones académicas, acaso canónicas, regidas por la proporción de las formas que proponen una belleza ideal. Eso no es desconocido por Bataille quien distingue la figuración académica griega del caballo, de la figuración de los galos, monstruosa, que infecta la corrección de los animales académicos. ${ }^{46}$ En "El lenguaje de las flores" se deja en claro ese deslizamiento de sentido y el uso ideal de las flores en la oscura desproporción monstruosa que retrató Karl Blossfeldt: ${ }^{47}$ parecen abrir sus fauces para devorar a quien las mira.

44 Bataille, Documentos, 86.

45 Bataille, Documentos, 86.

46 Bataille, Documentos, 25.

47 En este texto Bataille considera las relaciones entre los signos inteligibles y los estados del espíritu: si la flor comúnmente es el signo de la elegancia galante de la seducción romántica, Bataille asumirá la posición en que la flor es el índice de la desproporción. La visión de una flor nos toca, viola las taxonomías y revela "una oscura decisión de la naturaleza”. Bajo la lógica del inconsciente, Bataille señala los múltiples desplazamientos que hacen aceptables los objetos del deseo (del órgano a la persona, de los estambres y pistilos a los pétalos que los rodean). Así, lo que consideramos bello de las flores está adecuado a lo que debe ser según un ideal humano. Sin embargo, las flores también se des-componen. 
Así, el materialismo batailleano que se lee en Documents no sólo teoriza sobre la materia y aquello insumiso a la levita académica; lo que podemos inteligir o jerarquizar; también practica esa composición con lo bajo de la materia, eso que Didi-Huberman llama pliegue o montaje. ${ }^{48}$ El montaje de imágenes que compone con lo bajo e informe, el montaje en tanto descomposición de las formas por el choque de las imágenes, es la operación práctica (no sólo teórica) en la cual este materialismo impugna un régimen del saber y otro de lo sensible. En suma, impugna una ontología.

Cuando referimos a la impugnación de la ontología, vale aclarar que lo bajo de la materia —leído desde la crítica de la ontología que entiende "lo que hay" desde la forma, lo cerrado y lo posible - asume el principio del mal. ${ }^{49} \mathrm{El}$ mal batailleano, al asumir el signo de la apertura, de lo imposible y de lo que comunica, impregna esta otra ontología donde la materia está expuesta a su exposición, a mostrarse en capas, en sus pliegues o a irrumpir en montajes de tiempos heterogéneos. Esa relación, si bien se hace patente entre lo bajo de la materia y el "uso" de las imágenes en el montaje, está presente en Documents como la operación para detonar y explotar un régimen de lo sensible y del sentido: ese que idealiza lo que hay y sus contactos.

Las operaciones que vinculan materialismo bajo y montaje encuentran su punto más álgido en Documents, en la perturbación de la figura

Como sostiene Neuburger: "El montaje en Didi-Huberman convoca una operación próxima al movimiento de la interrupción, una doble articulación del procedimiento que supone en principio un desmontaje, una separación de los elementos que la componen para luego remontar esas piezas, recomponer sus sentidos. Esta operación no sólo custodia la visualidad de una constelación de sentidos, sino que, además, asegura su propia legibilidad". Neuburger, "El presente...”, 49.

49 Al modo como aparecerá luego en Sobre Nietzsche o en La literatura y el mal: como la transgresión de los seres y de su cierre. El mal, más allá de la concepción habitual o mejor, invirtiéndola, es lo que relaciona, lo que comunica, lo que lleva a romper los límites de los seres. La moral de la cumbre que Bataille trazó en Sobre Nietzsche señala que: "No comunico más que fuera de mí, soltándome o arrojándome fuera. Pero fuera de mí, yo no soy”. Georges Bataille, Sobre Nietzsche, traducción de Fernando Savater (Madrid: Taurus, 1972), 53. 
humana, en la reconfiguración de los cuerpos, en la torsión del sentido de las flores, en la monstruosa exhibición de lo bello, de la autoridad, y es también rastreable su impronta en la obra didi-hubermaniana. Se hace patente en la insistencia de Didi-Huberman sobre la exposición de las paradojas y tensiones: entre la historia integral y la historia universal, ${ }^{50}$ entre memoria y pregunta por el horror; ${ }^{51} \mathrm{y}$ por medio del señalamiento de "un nuevo montaje de los tiempos perdidos [...] que muestra y expone los movimientos de su propia materia histórica" ${ }^{52}$ Lo temporal benjaminiano y lo material, más en sintonía batailleana, se encuentran, chocan y confluyen en la lectura didi-hubermaniana de la imagen, profundizando ese carácter material de lo temporal propio de la operación de montaje.

Así, al convocar principalmente el registro temporal del montaje, Didi-Huberman asume, por sobre otros aspectos, el elemento del tiempo en la materia, sin idealizar lo que allí se pliega. Lo informe, lo bajo, la "insumisión material de los hechos" batailleanos promueve acaso esa cualidad específica del montaje que permite ver en las imágenes, por un lado, la supervivencia de los tiempos en la historia y, por otro, la puesta a prueba de la imaginación política y social. Crítica al montaje que, reconociendo las capas de tiempos, materialidades y conflictos puede, no obstante, abrirse a una heurística de la sublevación.

Ese vínculo entre materialismo bajo y montaje se hace patente en los desarrollos de Didi-Huberman sobre el "humanismo más íntegro", donde reconoce en Bataille un "humanismo herido, agujereado, un humanismo capaz de considerar al hombre con su incompletud misma", ${ }^{53}$ donde la violencia y la locura por dar rostro a la finitud se entienden como crí-

50 Ver Georges Didi-Huberman, Pueblos expuestos, pueblos figurantes, Horacio Pons, trad. (Buenos Aires: Manantial, 2018).

51 Ver Georges Didi-Huberman, Cortezas, Mariel Manrique y Hernán Marturet, trads. (Cantabria: Shangrila, 2014).

52 Didi-Huberman, Pueblos expuestos, 30 (el subrayado de la palabra “materia” es nuestro).

53 Didi-Huberman, Pueblos expuestos, 97. 
tica a la violencia social. Es también este humanismo de la incompletud el que puede provocar la imaginación social, alterando y reinventando lo humano en el espacio de una política otra de la comunidad, "un tipo de apuestas cruzadas de la estética y la política". ${ }^{54}$

Es la gaya ciencia visual de Documents, que pone en juego los límites del pensamiento y la figurabilidad, lo que Didi-Huberman subraya en Bataille: ${ }^{55}$

Bataille había hecho surgir toda una serie de experiencias anómicas y de objetos-parias de la historia del arte o de la literatura: por ejemplo las "fatrasías" medievales estudiadas desde 1926, las monedas galas anti-clásicas, las representaciones de la Gnosis en los intaglios monstruosos de la Antigüedad tardía o incluso la violenta suntuosidad del Apocalipsis de San Severo, ejemplos que proliferan en el extraordinario "atlas heterológico" que constituyó, entre 1929 y 1930 , la revista Documents. ${ }^{56}$

Esta gaya ciencia tiene relevancia también para el trazado de una ética y una política de la imagen, para lo cual basta con volver a Cortezas y reconocer el trabajo sobre lo inimaginable en los campos de concentración que Didi-Huberman visitó y fotografió. La materia allí aparece como testigo, como desecho y también como corteza o superficie de inscripción de gestos de resistencia y escritura. Acaso no sea casual el modo en que

54 Didi-Huberman, Pueblos expuestos, 105.

55 Este materialismo insumiso presente de forma tan contundente y explícita en esta publicación de la década de 1930 es reconocible en otras obras de Bataille como los desarrollos teóricos del Colegio de sociología sagrada, en la crítica a la política de "En la estructura psicológica del fascismo" o a la economía teórica en "La noción de gasto", y en el pliegue de pensamiento e imagen en Las lágrimas de Eros, en cuya materialidad se hace patente la necesidad de pensar lo imposible y hacerlo por vía de la imágen. Ver Georges Bataille, Las lágrimas de Eros, David Fernández, trad. (Barcelona: Tusquets, 1997).

56 Didi-Huberman, "El arte de la vida otra", 10. 
Didi-Huberman recupera el elemento bajo de la materia de las cenizas de los campos a partir de volver y trocar "El lenguaje de las flores" de Bataille, cuando reconoce "con el corazón estrujado, esa pululación bizarra de flores blancas en el lugar exacto de las fosas de cremación": ${ }^{57}$ paradójica exuberancia de la materia montada sobre la hecatombe humana.

Éste es el legado batailleano que reconocemos de forma contundente en Didi-Huberman: la perspectiva materialista expuesta a lo bajo (donde lo bajo puede tomar el modo de lo informe, de lo abyecto, lo sagrado impuro, lo monstruoso, lo inhumano, de la herida, la desproporción, lo imposible): un conocimiento experimental de "formidable potencia heurística, estética y política, todo al mismo tiempo". ${ }^{58}$

\section{Del antropomorfismo desgarrado a las sublevaciones}

Didi-Huberman retoma de Bataille esa perspectiva en la cual el régimen de la semejanza —interminable recomienzo que reenvía siempre a otra semejanza— ${ }^{59}$ está atravesado por lo informe, aquí puntualizado, en torno a un materialismo insumiso. Se trata de un reenvío de una semejanza a otra tramada desde lo informe, desde la materialidad de sus transformaciones y su des-composición. Este materialismo hace suya la herida

57 Didi-Huberman, Cortezas, 56.

58 Didi-Huberman, "El arte de la vida otra”, 10.

59 La cuestión de la semejanza como "posibilidad de recorrer una distancia” y la reverberación que cobra en las lecturas y desarrollos de Didi-Huberman es tan vasta que merecería un estudio in extenso abocado sólo a esta noción. A efectos de señalar algunos puntos de esa trama mencionamos: la semejanza no sensorial, las semejanzas virtuales en la imagen, el interminable recomienzo de semejanza, la semejanza como interrogación y deseo, la semejanza como estructura del sueńo. Como ejemplo de "un punto que se corre" al destejer la noción de semejanza en Didi-Huberman, ver "De semejanza a semejanza”, Noelia Billi, trad., en Instantes y azares. Escrituras nietzscheanas, núm. 11, Ańo XII (primavera de 2012), 291-319. 
y el desgarramiento, la apertura y la fisura, el detritus y los desechos, lo expuesto y lo infecto. No idealiza la materia, la toma en sus transformaciones. Reconoce la distancia y la separación, pero la atraviesa gracias a la semejanza que permite recorrer la distancia.

Ese materialismo de lo bajo perturba la historia del arte y de la historiografía por vía de la imagen. Para Didi-Huberman la imagen no es un "simple soporte de iconografía", ${ }^{60}$ antes bien es el espacio de perturbación de lo visual y lo temporal, el instante en que se reúnen y chocan el objeto visual y un sujeto de la mirada, ${ }^{61}$ se reúnen y juntan un trozo del pasado y el ahora. ${ }^{62}$

Aquella noción de imagen que encontramos en Ante el tiempo, en donde "La imagen no es la imitación de las cosas, sino el intervalo hecho visible, la línea de fractura de las cosas", ${ }^{63}$ introduce ese elemento de corte, lo abierto, lo herido, que propone el desgarramiento como vector de sentido (sens que pliega sensibilidad y significación) de la historia del arte, de la antropología de las imágenes, pero también de la ontología. Si partimos de que la imagen es "objeto del ver y de la mirada", ${ }^{64}$ un "delante adentro", no hay manifestación total de la cosa en la imagen; hay una semejanza en la cual la imagen vacila en su mostración, para la

Los elementos de choque, de lo inasimilable, lo bajo de la insumisión contagiosa son algunos motivos de Bataille que retoma Didi-Huberman. Acaso valga señalar, acerca del sentido del contagio, la influencia de la escuela sociológica francesa que Bataille plegó y tensionó a la teorización psicoanalítica freudiana de los lazos pulsionales con los objetos. Para ahondar en esta caracterización recomendamos el libro de Gibrán Larrauri Olguín, Bataille y el psicoanálisis. La heterología, Freud y Lacan (Ciudad de México: Navarra, 2015).

62 En este sentido, ver una imagen no supone la trasposición directa de lo que se ve a lo que es posible decir, porque la imagen es en el tiempo, las lecturas, interpretaciones, interrupciones y contactos que permite no están dadas de una vez hacia adelante, sino que irrumpen en el tiempo. Como ante la puerta kafkiana, mirar la imagen es "desearla, es esperar, es estar ante el tiempo". Didi-Huberman, Ante el tiempo, 31.

63 Didi-Huberman, Ante el tiempo, 166. La cursiva es nuestra.

64 Didi-Huberman, Lo que vemos, 169. 
mirada, puesto que la mirada la hace vacilar y la lleva hacia la imagen. El elemento pulsátil de la comunicación, la intermitencia del contacto — ni totalmente cerrado ni totalmente abierto - da cuenta de lo recorrido por la semejanza: "Las imágenes se abren y se cierran como nuestros cuerpos que las miran", ${ }^{65}$ este paralelismo propicia la puesta en relación de las imágenes bajo el signo de un antropomorfismo. En Bataille, se trata de un antropomorfismo desgarrado; en Didi-Huberman de un antropomorfismo de la semejanza, sin descuidar el posicionamiento de la mirada y lo mirado en una doble situación: "de un lado, la localización sensible del conocimiento y, por el otro, la corporización de la mirada para desplegar un discurso más o menos articulado sobre la visualidad sin un punto privilegiado de la vista" ${ }^{66}$ Ambos antropomorfismos se concentran en la propuesta de una experiencia interior (las imágenes que se abren a y se cierran sobre nosotros, dirá Didi-Huberman en L 'image ouverte).

En la antropología de las imágenes propuesta por Didi-Huberman es central la experiencia interior en tanto subraya que, así como nuestro cuerpo se abre y se cierra, las imágenes hacen lo mismo, ocultan e indican, pero no de una vez y para siempre; no para asumir una forma estática y verdadera, sino que son comprendidas o accedemos a ellas como síntomas, es decir, en su modo de mostrarse (y cerrarse), en sus metamorfosis. Desde el signo de la semejanza que relaciona unos cuerpos con otros, unas imágenes con otras imágenes, imágenes y cuerpos.

Así, la semejanza informe batailleana, asumida por Didi-Huberman, sitúa la posibilidad de dar cuenta de las imágenes por una semejanza antropomórfica (no ya ideal, ni divina): "Decir que las imágenes se abren y

65 Georges Didi-Huberman, L'image ouverte. Motifs de l'incarnation dans les arts visuels (París: Gallimard, 2007), 25.

66 Eliza Mizrahi "Ver y saber en torno a la imagen”, en Georges Didi-Huberman, Sublevaciones, Susanna Méndez, Xavier Rodrigo y Mercè Ubach, trads. (Ciudad de México: muac-unam, 20 I 8), 168. 
se cierran como nuestros cuerpos que las miran, es decir, que las imágenes son creadas por nosotros a nuestra imagen: no solamente a la imagen de nuestro aspecto, sino a la de nuestros actos, de nuestras crisis, de nuestros propios gestos de apertura" ${ }^{67}$ Bataille está presente en esta perspectiva además del no-saber, la heterogeneidad, lo bajo y la materia insumisapor la indicación de la apertura como exposición a lo impensado, el síntoma, la supervivencia, lo imposible, vale decir, a la experiencia interior.

En esta antropología, la mirada (como un adentro de la imagen) es la que despliega su valor sintomático: eso que hace callar a un sujeto que se supone que habla; que hace errar a un sujeto que habla y conoce; que hace olvidar a un sujeto que se supone recuerda. El elemento de no-saber que se hace presente en el contacto con las imágenes revela, a su vez, la encarnadura del inconsciente. Desde allí es posible pensar la imagen como síntoma.

$\mathrm{Si}$ "El síntoma es, en primer lugar, el mutismo en el sujeto que se supone que habla" ${ }^{68}$ la imagen como síntoma viene a desmentir la correspondencia entre lo que vemos y lo que está allí, al frente. El elemento de falla en la imagen, que nos mira en lo que vemos, señala hacia esa grieta móvil, en la cual la interpretación puede ser puesta en acto, revocada e iniciada nuevamente.

El matiz batailleano de esta antropología acentúa su elemento de desgarramiento, de la herida en dos sentidos: en el sujeto, que ya no es lugar de la certeza, sino el espacio y el tiempo encarnado de contacto y la apertura tensada hacia la experiencia que lo disloca; y en la imagen que, operando sobre el espacio y también sobre la temporalidad, está abierta a lo impensado, perturbando el sentido. La imagen aparece en su doble bind, como objeto y como operación del sujeto, imbricados en el objeto visual y en el sujeto de la mirada.

67 Didi-Huberman, $L$ 'image ouverte, 30 (La traducción es nuestra).

68 Jacques Lacan, Seminario 11: Los cuatro conceptos fundamentales del psicoanálisis, Juan Luis Delmont-Mauri y Julieta Sucre, trads. (Buenos Aires: Paidós, 2006), 19. 
En los ensayos reunidos en La imagen abierta — donde se problematiza esa apertura de la imagen y el cuerpo en la encarnación-, la imagen cobra el sentido antropológico en el cual insistimos: "en tanto que acontecimiento, acto, alteración donde, de parte a parte, nuestro cuerpo se encuentra implicado, puesto en movimiento". ${ }^{69}$ El desgarramiento de la imagen y el cuerpo da cuenta del ritmo de sístole y diástole de la pulsión, y también inyecta el elemento heterogéneo de una desmesura, pues "abrir supone herida y crueldad". ${ }^{70}$ En términos didi-hubermanianos la imagen se aleja de las síntesis tranquilizadoras de las distancias sujeto/ objeto, antes bien es síntoma, crisis, deslizamiento que, si tiene la apariencia de síntesis dialéctica, no es más que una trampa en espera del próximo desgarro.

En la imagen abierta didi-hubermaniana el antropomorfismo desgarrado batailleano señala, además, hacia ese mundo de sentidos abierto a los conflictos. Abrir es desarmar una trama apretada, cerrada, es expandir y exponer los bordes o los límites; también desollar, rajar la mirada. Todos estos movimientos incitan una forma de destrucción, dejar entrar la alteridad de la heterogeneidad, romper las formas sólidas para que ingrese lo real. "La imagen deviene entonces nuestro objeto de no-consolación. Porque ella se abre sobre lo informe de su [de nuestra] propia constitución". ${ }^{71}$

La exigencia batailleana de una visión sin nombre es redireccionada por Didi-Huberman hacia la exigencia de una imagen inconsolable, que remite a la interpelación de la experiencia interior de conmoción y despliegue del sujeto. Nos interesa marcar que la experiencia interior descrita por Bataille ya suponía un marco visual para la apertura del sujeto: el entendimiento que puede ver $y$, sin embargo, tiene un punto

69 Didi-Huberman, $L$ 'image ouverte, 35.

Didi-Huberman, L'image ouverte, 54.

Didi-Huberman, L'image ouverte, 62. 
ciego, "que recuerda a la estructura del ojo", pero, a diferencia del punto ciego del ojo casi sin consecuencias, el punto ciego del entendimiento "tiene más sentido que el mismo entendimiento"; ${ }^{72}$ ese punto ciego del entendimiento es la noche a la que se abre el sujeto y lo absorbe. Este marco óptico de la experiencia interior indica, en Bataille, su límite y su transgresión: no sólo el límite del entendimiento, también de lo decible, de lo nombrable. Por ello, la imagen se expande hacia la imaginación y a una práctica que cobra los nombres de mitologización (principalmente en El ojo pineal de 1927) y dramatización (en La experiencia interior y El culpable).

Mitologizar es la operación propuesta por Bataille para ensanchar más la herida del entendimiento, para convulsionar el tipo de experiencia soberana o insumisa a la que alude: "Está claro que el mundo es puramente paródico, es decir, que cada cosa que miramos es la parodia de otra, o incluso la misma cosa bajo una forma engañosa", ${ }^{73}$ y "Los ojos humanos no soportan ni el sol, ni el coito, ni el cadáver, ni la oscuridad, sino con reacciones diferentes" ${ }^{74}$ Bataille propone mitologizar sobre un ojo soberano, erecto, sublevado, un ojo pineal que capte lo imposible: mirar de frente al sol. En esta antropología mítica (ya no científica, aunque dispone de la ciencia, pero con un fin contrario ${ }^{75}$ ), el mito es una consumación violenta de una verdad, o mejor, la consumación de una virtual soberanía del ser.

En esta operación que Bataille pone en marcha tempranamente, en la que se da la consumación de un esquema visual que se rebela contra la servidumbre del sentido humano, la imagen opera como un dispositivo (resorte o trampolín) para incitar otras formas de lo humano; no se redu-

Bataille, La experiencia, 140.

Georges Bataille, "El ano solar", en El ojo Pineal, Manuel Arranz, trad. (Valencia: Pre-Textos, 1997), 15.

Bataille, "El ano solar", 20.

Bataille, El ojo pineal, 55-81. 
ce al cálculo, a lo racional ni a lo ideal ni a la sumisión útil y, a su vez, no desconoce las contradicciones, la crueldad y la violencia. ${ }^{76}$

Respecto a la dramatización que promueve y provoca la experiencia interior, también tiene un marco óptico: el movimiento de ver a la mirada como objeto de la pulsión, donde el objeto de la mirada es objeto de éxtasis. Es decir, hay un objeto que se desea ver, pero ese objeto se desvanece. Pero no es sólo ver, sino dramatizar, extender, abrir, desplegar el objeto de la mirada, aun cuando ya no está presente a la mirada, pero está aún abierto a la experiencia en la cual "el espíritu es un ojo", ${ }^{77}$ se convierte en él en la experiencia. Ese punto — grieta que se abre— no es alcanzado sino mediante la dramatización. ${ }^{78}$

76 No tomaremos aquí las derivas de esta antropología en los términos del erotismo (ni la centralidad de conceptos como desnudez, cuerpo, deseo, carne, mirada, violencia, violación, transgresión) tan presentes a lo largo de la obra de Georges Bataille (desde la década de 1920 con El ojo pineal y El ano solar tienen una primera formulación hasta los desarrollos de El erotismo y Las lágrimas de Eros, allende los escritos literarios que encuentran su cumbre en Madame Edwarda, Historia del ojo y Mi madre, en los cuales el erotismo tiene un marco óptico: el ojo es tomado como órgano sexual y la mirada resulta objeto de la pulsión erótica. Asimismo, tampoco consideramos las derivas y expansiones en la obra de Georges Didi-Huberman de la imagen abierta tramada en torno al erotismo, la desnudez y la carne, presente en Venus rajada. Desnudez, sueño, crueldad, Juana Salabert, trad. (Buenos Aires: Losada, 2005) y en L'Image ouverte para tensionar los motivos de la encarnación cristiana con el erotismo a la Bataille. Sin embargo, creemos necesario señalar que la vastedad e importancia de los motivos del erotismo demanda un trabajo en extensión abocado solamente a tal fin. Vale como indicación de su importancia la torsión constante entre la soberanía y el erotismo como efusión, tensadas ambas en Bataille por la transgresión y el trazado de una antropología de las imágenes que siempre involucró el deseo y la carne, hacia una antropología de las imágenes políticas. En Didi-Huberman la sublevación o la desobediencia asume la fuerza del deseo y también del rechazo, en los cuerpos, en los gestos, en la memoria. Sublevaciones y Desear desobedecer son ejemplos contundentes de ese reciente trazado.

77 Bataille, La Experiencia, 148.

78 ¿Qué es dramatizar? Bataille refiere un ejercicio espiritual (señala como caso la práctica religiosa de los devotos que siguen los ejercicios de San Ignacio, pero no sólo se circunscribe a ella) en donde se pone en juego la imaginación, una representación teatral, un drama. Aquí vale señalar el papel central de la imaginación, de salir de sí y de la conmoción y contacto que pueden provocar las imágenes. 
Esas dramatizaciones o mitologizaciones son rescatadas por Didi-Huberman en La dama duende: ¿qué sería de la experiencia humana del arte sin la dramatización, sin las mitologizaciones que, a modo de exigencia, enfrentan y se rebelan a la matriz utilitaria, apolínea y lineal de la modernidad? Desde aquí, el arte es motor de la efusión, instancia de comunicación, aunque esté perturbado —o precisamente porque lo está- el régimen de la belleza que se le adjudicaba (si la belleza académica es resultado de la simplificación geométrica de las líneas, una belleza no reducida involucra desplazamientos, superposiciones, lo obsceno y lo informe bruto). Si el arte no remite necesariamente a la búsqueda de la belleza comprendida como forma ideal, normalizadora, de una experiencia es posible apuntar entonces que el arte señala hacia una experiencia (un ejercicio de crueldad dirá Bataille) de contacto, de comunicación. De allí la centralidad de la experiencia con las imágenes que, más que convocar a la belleza, invitan a la violencia o el trastorno (no alejadas de aquella experiencia religiosa de lo sagrado heterogéneo). ${ }^{79}$ De la insistencia obsesiva de Bataille en torno al cliché del suplicio de los cien pedazos, nos queda la sugerencia de que, si bien hay una experiencia de comunicación, la misma es no discursiva:

Recurrí a imágenes perturbadoras. En particular, me fijaba en la imagen fotográfica —o a veces recordándola — de un chino que debió ser sometido al suplicio durante mi vida. Anteriormente había tenido una serie de representaciones sucesivas de ese suplicio. Al final, el paciente, con el pecho desolla-

Sabemos que en los últimos años de su vida Bataille se dedicó a dar forma a un tipo de saber en el cual el pensamiento filosófico y el arte eran puestos en contacto, más por choque que por diálogo, esto dio lugar a Las lágrimas de Eros. Allí dos formas de la impureza se encuentran no para explicar la verdad de la obra de arte, ni para dar expresión artística al saber o ilustarlo. Se trata más bien de interpretar, ¿por qué aquí esta palabra mágica? No sólo porque interpretar es estar entre dos cosas que se precian, traficando con su valor y medida, sino porque interpretar también es irrumpir, interrumpir, cortar, cambiar de registro. Producir con el síntoma. 
do, se retorcía, cortados los brazos y piernas en los codos y en las rodillas. Los cabellos erizados sobre la cabeza, asqueroso, despavorido, veteado de sangre, bello como una avispa.

Escribo "bello" ..., algo se me escapa, me huye, el miedo me sustrae de mí mismo, y mis ojos resbalan como si hubiese querido mirar fijo el sol. ${ }^{80}$

En torno a la fijación en esas imágenes conmovedoras, ${ }^{81}$ la dramatización es una operación de ruina, de apertura a la ruina, y desde allí apunta a lo que Didi-Huberman postula como la posibilidad de "vivir una vida otra" ${ }^{82}$ abrirse a esa vida otra, incluso sufrir o padecer - por contagio, por comunicación-. Esta operación impulsa, a nuestro entender, la puesta en acto de lo sensible como crítica radical a la modernidad y a la servidumbre que enclaustra todo.

Esta vida otra desde lo sensible, presente en "El aprendiz de brujo" como la apuesta de salir de la vida fragmentada y atravesar bajo el signo de lo sensible la posición del artista, del científico y del político, ¿no es acaso a lo que apunta la antropología heterológica batailleana que, atravesada por la contundencia de lo que arruina y la herida, puede también tensar esa vida otra hacia la soberanía? En la apuesta por una vida otra, el valor de la transgresión es clave: se transgrede el límite de lo cerrado, de los tiempos, del goce, y de la mirada conmovida. Se quiere mirar de frente al sol, la herida pretende elevarse más allá de su repulsión.

El giro político de la atención a las imágenes patente en la obra de Didi-Huberman está atravesado por este movimiento en torno a lo sensible

80 Bataille, La experiencia, 150.

81 Sin dudas aquí la fijación es múltiple: la primera es la de la luz que fija esa imagen en la fotografía, la segunda es la fijación angustiosa de quien ve al supliciado y, como no, la última es la fijación de eso que, en palabras de Didi-huberman, nos mira en lo que vemos, la ruina que desencadena: sobre la imagen del joven chino dice "lo amaba con un amor donde no participaba el instinto sádico: él me comunicaba su dolor o, más bien, el exceso de su dolor, y era justamente lo que yo buscaba, no para gozar de ello, sino para arruinar en mi lo que se opone a la ruina”. Bataille, La experiencia, 151.

82 Didi-Huberman, "El arte de la vida otra”, 12. 
en la experiencia de las imágenes: el deseo de desobedecer que Didi-Huberman formula como una puesta en movimiento de una vida otra, una vida soberana, en otros términos, la apuesta a una insumisión voluntaria. ${ }^{83}$

Lo rasgos de esta antropología batailleana que tiende a la soberanía (no sin mostrar su imposibilidad, su tragedia) son los que Didi-Huberman hace suyos en los desarrollos más recientes de su trabajo: "Nadie ha expresado mejor que Bataille el valor transgresor del deseo como potencia de sublevación"; ${ }^{84}$ la exuberancia (del erotismo) no es distinta de la rebelión (política). Como bien reconoce el autor de Sublevaciones, desde la clave de la transgresión, tanto el erotismo como la rebelión están en el mismo campo de agitación.

La sublevación, afirma Didi-Huberman, implica el gesto de deseo y también el de rechazo. ${ }^{85}$ La revuelta puede iniciarse humildemente, pero continúa, se propaga, cobra diversos cursos. Desde aquí, la transgresión no es entendida como superación, sino como motivo y movimiento hacia la sublevación. La desobediencia, la apertura a lo que en nosotros se subleva, sin embargo, no remite a una excepcionalidad ni a una jerarquía que sustente esa excepcionalidad. Tampoco hay una linealidad de la vida insumisa: más bien una suerte de operación artística (donde la dramatización y la mitologización juegan un papel central, piedra de toque de lo que se despierta, lo que despabila la memoria) dispuesta a encender una experiencia de comunicación.

En esta radicalización de la antropología de las imágenes hacia la política es posible reconocer la propuesta de Bataille en cuanto a la soberanía. Como subraya Didi-Huberman: "No habrá sublevación digna de este nombre sin asumir cierta experiencia interior radical" ${ }^{86} \mathrm{Del}$

\footnotetext{
83 Didi-Huberman, Desear desobedecer.

84 Didi-Huberman, "Por los deseos", 109.

85 Didi-Huberman, "Por los deseos", 131.

86 Didi-Huberman, "Por los deseos", 88.
} 
materialismo batailleano a una apertura radical y, de allí, a la soberanía como una vida otra. Los rasgos de la soberanía heterogénea de Bataille, pensada como subjetividad profunda y desgarrada, abren camino hacia una insubordinación generalizada, ${ }^{87}$ forma de vida que supone (en su virtualidad) la comunicación, la apertura.

En la antropología política didi-hubermaniana de las imágenes, el no-saber inquietante cobra toda su potencia: no sólo como archivo de

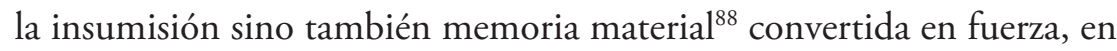
contagio, en elemento de choque que puede levantarnos hacia una vida otra. Aun en gestos humildes, en elementos desclasados, conflictos desencadenados, una fuerza que se subleva. El encendido de una mecha que, aún a través de movimientos simples, desencadena una potencia, gesto que una vez iniciado se propaga.

\section{A modo de cierre}

En este texto propusimos reconocer elementos batailleanos en el pensamiento sobre la imagen de Georges Didi-Huberman. Bataille aparece

87 En la noción de soberanía es posible reconocer la insubordinación y la constitución de un tipo de subjetividad que no se cierra en su ipseidad, apunta hacia la experiencia de la comunidad atravesada por las dimensiones heterogéneas de la razón y el cálculo. Al definir el sujeto por su insumisión, o su no-sujeción, se revela el punto problemático de la soberanía batailleana: la conjunción de la insubordinación del sujeto y de los sujetos, sus semejantes; se plantea la paradójica posibilidad de que el sujeto sea reconocido como subjetividad soberana, sin que el reconocimiento de la subjetividad suponga la necesidad de la subordinación servil a los otros. En suma, la soberanía en Bataille implica una subjetividad no reducida al reconocimiento que la vuelve servil, pero atada al reconocimiento (comunicación) de los semejantes. Una soberanía tramada desde la insumisión de Nietzsche (pero sin aristocratismo), Sade (sin excepcionalidad), con la revuelta de Marx, desde el infantilismo kafkiano y expuesta a la comunicación intensa y al gasto (Mauss). Para ampliar esta lectura ver Lorio, Georges Bataille, 217-325.

88 Eliza Mizrahi "Ver y saber”. 
aquí propiciando una serie de conceptos, nociones y dispositivos metodológicos que intervienen en la apertura epistémica de la historia del arte, en el trazado de una antropología materialista de la semejanza desde lo informe y lo bajo- y en la radicalización de ésta en una antropología política de las imágenes.

La apertura y el desgarramiento atraviesan la lectura de Bataille realizada por Didi-Huberman en la cual ponderamos la pregnancia de lo sensible respecto al saber, la forma y el contacto con lo pulsional, y en cuanto a la experiencia interior radical en los gestos de sublevación. Así, del antropomorfismo desgarrado batailleano hemos señalado rasgos, instancias, miradas, semejanzas (no para mostrar su unidad, sino su relación) y contagio hacia la heurística didi-hubermaniana que, entre rasgadura y deslizamiento, se presenta como una apuesta potente (teórica y en obra) por la materialidad heterológica de las imágenes y los gestos insumisos que incitan.

En el primer apartado profundizamos en la noción de no-saber, en la exposición de una comunicación desnuda, abierta a la desclausura del saber y las disciplinas; retomamos Documents, al considerar este proyecto una cristalización privilegiada de una suerte de materialismo insumiso, síntesis convulsiva e inquietante de una época, síntoma que arremete contra lo que cierra la forma y contra lo que cumple el círculo del saber. En el segundo apartado, tomamos la modulación del materialismo desde la perspectiva de lo bajo. En su singular posición asume el gesto de plegar los cruces de disciplinas y prácticas, como la antropología, el psicoanálisis y la estética, a ciertas operaciones de las vanguardias artísticas de principios de siglo Xx. A la luz de las recientes indagaciones y apuestas de Didi-Huberman, en el último apartado, consideramos la contorsión de las imágenes y los gestos bajo la exigencia de un pensamiento y una sensibilidad política de la sublevación y el desobedecer, hilvanando lo que pueden tomarse como operaciones soberanas batailleanas.

En atención a los rasgos de esta apertura consideramos los diferentes modos en que el pensamiento de Bataille propicia, modula o acompaña 
los desarrollos teóricos de Didi-Huberman, desde la semejanza, la metamorfosis, desde lo que subleva. Los pliegues que hemos propuesto en este texto buscaron más que hacer coincidir, reconocer puntos de contacto, contagios, situar reverberaciones de un pensamiento, de la experiencia de la imagen; ojalá, permitan posicionar más ampliamente la apertura de la operación didi-hubermaniana.

Para terminar, quisiéramos insistir en la trama compleja que aúna en la experiencia radicalizada de las imágenes elementos inasimilables. Si bien la experiencia tiene un marco óptico, es preciso no dejar de notar la violencia que pone en juego. Aquello que Didi-Huberman reconoce en Bataille respecto a la imagen abierta en un espacio ateólogico, es tensado, asumido y tomado como relevo para una crítica que disemina y hace estallar desde la historia del arte, hacia una antropología de las imágenes y así remarcar el carácter político de la imaginación, los gestos y las imágenes. Entendemos que esos pliegues muestran las dimensiones y direcciones de la perspectiva didi-hubermaniana: la materia flexible y la curva de su contorsión, los estratos de su pensamiento y la operación de apertura a registros y contagios de una memoria de la insumisión. 


\section{Referencias}

Bataille, Georges. Documentos. Traducido por Inés Cano. Caracas: Monte Ávila editores, 1968.

. Euvres complètes, vols. VII, VIII. París: Gallimard, 1970-1988.

- Sobre Nietzsche. Traducido por Fernando Savater. Madrid: Taurus, 1972.

- El ojo Pineal. Precedido de El ano solar y Sacrificios. Traducido por Manuel Arranz. Valencia: Pre-Textos, 1997.

. Las lágrimas de Eros. Traducido por David Fernández. Barcelona: Tusquets, 1997.

- La experiencia interior. Suma ateológica I. Traducido por Silvio Mattoni. Buenos Aires: El cuenco de plata, 2016.

- El culpable. Suma ateológica II. Traducido por Silvio Mattoni. Buenos Aires: El cuenco de plata, 2017.

Colectiva Materia, coordinadoras. Indisciplina. Estética, politica y ontología en la revista Documents. Buenos Aires: Ragif Ediciones,2019.

Didi-Huberman, Georges. La ressemblance informe-ou le gai savoir visuel selon Georges Bataille. París: Macula, 1995.

- Venus rajada. Desnudez, sueño, crueldad. Traducido por Juana Salabert. Buenos Aires: Losada, 2005.

. L 'Image ouverte. Motifs de l'incarnation dans les arts visuels. París: Gallimard, 2007.

- Ante la imagen. Pregunta formulada a los fines de una historia del arte. Traducido por Françoise Mailler. Murcia: Cendeac, 2010. . Lo que vemos, lo que nos mira. Traducido por Horacio Pons. Buenos Aires: Manantial, 2010.

- Ante el tiempo. Historia del arte y anacronismo de las imágenes. Traducido por Antonio Oviedo. Buenos Aires: Adriana Hidalgo, 2011. . "De semejanza a semejanza”. Traducido por Noelia Billi. Instantes y Azares. Escrituras nietzscheanas núm. 11, año XII (primavera de 2012): 291-320. 
. Cortezas. Traducido por Mariel Manrique y Hernán Marturet. Cantabria: Shangrila, 2014.

- La invención de la histeria. Charcot y la iconografía fotográfica de Salpêtrière. Traducido por Tania Arias y Rafael Jackson. Madrid: Editorial Cátedra, 2015.

- "Por los deseos (fragmentos sobre lo que nos subleva)". En: Sublevaciones. Traducido por Susanna Méndez, Xavier Rodrigo y Mercè Ubach. Saenz Peña: Jeu de Paume-Eduntref, 2017.

. Pueblos expuestos, pueblos figurantes. Traducido por Horacio Pons. Buenos Aires: Manantial, 2018.

. "El arte de la vida otra". CHUY Revista de estudios literarios latinoamericanos, número 5 (diciembre de 2018): 4-22.

. La dama duende. Traducido por Lucía Montes Sánchez. Madrid: Avarigani Editores, 2019.

- Desear desobedecer. Lo que nos levanta, 1. Traducido por Juan Calatrava y Alessandra Vignotto. Madrid: Abada Editores, 2020.

García, Luis Ignacio. La comunidad en montaje. Imaginación política y postdictadura. Buenos Aires: Prometeo, 2018.

García Vergara, Marisa. Georges Bataille y la parte del arte. De Documents a Acéphale. Barcelona: Universitat Autònoma de Barcelona, Universitat de Barcelona, Universitat de Girona, Universidad de Lleida, Universitat Politècnica de Catalunya, Universitat Rovira i Virgili, Museu Nacional d'Art de Catalunya, 2013.

Hollier, Denis. Documents. París: Jean Michel Place, 1991. https://gallica.bnf.fr/ark:/12148/bpt6k32952s.

Lacan, Jacques, Seminario 11: Los cuatro conceptos fundamentales del psicoanálisis. Traducido por Juan Luis Delmont-Mauri y Julieta Sucre. Buenos Aires: Paidós, 2006.

Larrauri Olguín, Gibrán. Bataille y el psicoanálisis. La heterología, Freudy Lacan. Ciudad de México: Ed. Navarra, 2015. 
Lorio, Natalia. "Una escritura a la caza de lo real. Lo heterogéneo, lo sagrado y la soberanía en Georges Bataille". El laberinto de arena, núm. 2, vol. 1 (invierno-primavera de 2013): 213-235. http:// www.hum.unrc.edu.ar/ojs/index.php/Filosofia/index.

- "Heterología. Cuestiones de método y otras consideraciones". En: Métodos. Aproximaciones a un campo problemático, 177-193. Buenos Aires: Ed. Prometeo, 2018.

. Georges Bataille. Una soberanía trágica. Adrogué: La Cebra, 2019.

Mizrahi, Eliza. "Ver y saber en torno a la imagen". En Sublevaciones. México: Jeu de Paume-muac-unam, 2018. https://muac.unam. $\mathrm{mx} /$ assets/docs/folio_064_sublevaciones.pdf

Neuburger, Ana. "El presente y sus restos. Arte, literatura e imagen en la estética contemporánea". La Palabra, núm. 37 (abril-junio de 2020): 41-56. https://doi.org/ 10.19053/01218530. n37.2020.8950.

Ollé-Laprune, Philippe. Para leer a Michel Leiris. Traducido por Glenn Gallardo, Flora Botton Burlá, Jorge Ferreiro, Mónica Mansour, Virginia Jaua. Ciudad de México: Fondo de Cultura Económica, 2010.

Sasso, Robert. Georges Bataille: Le système du non-savoir. Une ontologie du jeu. París: Éditions de Minuit, 1978. 